\title{
In-Vitro androgenesis in papaya (Carica papaya L.) cv. Pusa Nanha
}

\author{
Gyanchand ${ }^{1}$, Manoj Kumar Sharma', Sandeep Kumar ${ }^{1}$, Sushma Sagar ${ }^{1}$, Vinay Kumar ${ }^{2}$ \\ and Mukesh Kumar ${ }^{*}$ \\ ${ }^{1}$ Department of Agriculture Biotechnology, S. V. P. University of Agriculture \& Technology, Meerut-250110 (U. P.), \\ INDIA \\ ${ }^{2}$ National Institute of Biotic Stress Management, Raipur (Chhatisgarh), INDIA \\ *Corresponding author. E-mail: mukeshbt06@gmail.com
}

Received: January 12, 2014; Revised received: March 21, 2015; Accepted: April 15, 2015

\begin{abstract}
Papaya (Carica papaya L.) is an economically important fruit crop of tropics and subtropics. It has high nutritional value, as well as medicinal and industrial applications. Papaya is a polygamous species with three sex types male, female, and hermaphrodite. Conventional methods of papaya breeding are time consuming and needs advent of anther culture which may be effective for shortening of breeding cycles. The present study on in vitro androgenesis in papaya $\mathrm{cv}$. Pusa Nanha observed the highest embryo induction rate (8.0\%) when anthers were cultured on agar medium with $0.1 \mathrm{mg} / \mathrm{L}$ BA and $0.1 \mathrm{mg} / \mathrm{L}$ NAA after incubation in liquid MS medium with $2.0 \%$ sucrose for 7 days at $35^{\circ} \mathrm{C}$. The high temperature $\left(35^{\circ} \mathrm{C}\right)$ was more suitable for embryo induction in papaya than slightly low temperature $\left(25^{\circ} \mathrm{C}\right)$. At these both temperatures longer incubation of anthers in water reduced embryo induction rate. Sugar starvation results were ambiguous. Shoots were also developed in the media when used in liquid form. The highest rooting $(75.0 \%)$ was observed at $2.0 \mathrm{mg} / \mathrm{L}$ IBA. Increasing IBA concentration reduced rooting. All well rooted plants were hardened in hardening chamber and successfully transferred to field. The present findings indicated that anther culture can be efficiently contributed for the direct micro-propagation of papaya plants. This study would also be helpful to the researchers to develop more efficient anther culture protocols for further improvement of papaya through in vitro androgenesis.
\end{abstract}

Keywords: Anther culture, embryogenesis, MS media, papaya, plant growth regulators

\section{INTRODUCTION}

Papaya (Carica papaya L.), a member of family Caricaceae, is the most economically valuable fruit crop, owing to its high nutritional value, as well as medicinal and industrial applications (Drew, 2003; Silva et al., 2007; Zhang et al., 2011). It consists 55 species placed under four genera, namely- Carica, Cyclimorpha, Jacaratia and Jarilla (Badillo, 1971; Dallwitz, 1980). Papaya is a rich source of antioxidants, vitamins (A, B, C and E), minerals (magnesium and potassium) and fibers. It contains a digestive enzyme papain that effectively treats causes of trauma, allergies and spots injuries. It is also used as a tonic to improve cardiovascular system, to treat dyspepsia, hyperacidity, dysentery, constipation, heart diseases and attacks, colon cancer and all types of digestive and abdominal disorders. Papaya is grown in around sixty countries, with the bulk of production in developing economies. Papaya is a major tropical fruit grown commercially in India, Brazil, Mexico, Australia, Hawaii, Thailand, South Africa, Philippines, Indonesia and Taiwan. India is the largest producer of papaya contributing more than $38.00 \%$ of the total world's production (Indian Horticulture database, 2011). Papaya is conventionally propagated by seeds, grafting and rooted cuttings but these methods often tedious and impractical when carried out on a large scale due to considerable variation in disease susceptibility, fruit quality and yield (Rajeevan and Pandey, 1986). Conventional methods of papaya breeding requires at least six to eight generations developing a homozygous line (Ray, 2002). Tissue culture has the possibility for overcoming problems of lack of efficient preparing materials associated with breeding programmes for cultivar improvement. These techniques could offer a valuable alternative and reliable procedure for mass propagation of homogenous and uniform plants for both commercial and research purposes. Anther culture is a promising technique for shortening the breeding cycle via haploid production. For the first time, the anther culture was reported by Guha and Maheshwari (1964) in Datura innoxia plant at the Botany Department, South Campus, University of Delhi. To date, androgenic haploids have been produced in over 170 species; several good reviews provide lists of these species (Maheshwari et al., 1982; Bajaj, 1983; Heberle-Bors, 1985; Dunwell, 1996). The first attempt to utilize anther culture in papaya breeding was made by Litz and Conover (1978, 1979). Beside this, in vitro androgenesis in papaya has also been reported recently by several other researchers (Tsay and $\mathrm{Su}, 1985$; Rimberia et

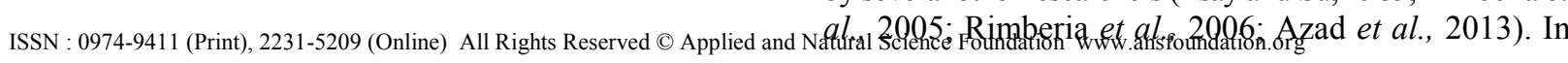


anther culture, it has been generally known that many factors (such as genotype and physiological state of the donor plant, physical and chemical factors of media, and developmental stages of pollen, pre-culture treatments) influence haploid induction efficiency (Sopory and Munshi, 1996). Therefore, the present research work was undertaken to investigate In vitro androgenesis in papaya (Carica papaya L.) cv. Pusa Nanha.

\section{MATERIALS AND METHODS}

Plant materials: In the present study, flower buds from papaya variety named 'Pusa Nanha' were used as plant material. The present work was carried out during 2012-2013 in Plant Tissue Culture and Molecular Biology laboratories at the Department of Agriculture Biotechnology, Sardar Vallabhbhai Patel University of Agriculture \& Technology, Meerut (U.P.) India.

Collection of anthers and surface sterilization: The healthy flower buds were collected from field grown plants during September - October, 2012 from Horticulture Research Centre, Sardar Vallabhbhai Patel University of Agriculture \& Technology, Meerut (U.P.). The flower buds were kept in $250 \mathrm{~mL}$ conical flask (Borosil, India) with mouth covered by muslin cloth under running tap water for $20 \mathrm{~min}$ followed by a by a 3 min treatment with a $5.0 \%(\mathrm{v} / \mathrm{v})$ aqueous solution of Laboline (Qualigens, India) and rinsed 5-6 times with sterilized distilled water. In a laminar flow hood, the flower buds were surface sterilized in $70 \%$ ethanol (Merck, USA) for $20 \mathrm{sec}$, then in $1.0 \%$ sodium hypochlorite (Merck, USA) solution containing 10 drops/L of Laboline (Qualigens, India), for 7-8 min and rinsed three times with sterilized distilled water.

In-vitro embryo induction and plant regeneration: After sterilization, anthers were aseptically removed under laminar air flow from the buds and pre-treated in liquid MS media (Murashige and Skoog, 1962) for 1, 4 and 7 days at 20,25 and $35^{\circ} \mathrm{C}$. For pre-treatment anthers were placed in test tubes containing: (1) water (distilled water without sucrose); (2) MS nutrients without sucrose; (3) MS nutrients with 2.0\% sucrose. The pre-treated, anthers were transferred on MS [19] agar medium supplemented with $0.5 \mathrm{mg} / \mathrm{L} \mathrm{BA}$ (Sigma, USA), $0.1 \mathrm{mg} / \mathrm{L}$ NAA (Sigma, USA), 3.0\% sucrose (Qualigens, India) and 0.6\% agar (Qualigens, India). The $\mathrm{pH}$ of the medium was adjusted to 5.8 with $1.0 \mathrm{~N}$ $\mathrm{NaOH} / \mathrm{HCl}$ before adding the gelling agents. Following autoclaving at $121^{\circ} \mathrm{C}$ and 15 psi pressure for $20 \mathrm{~min}$, the media were poured into $90-\mathrm{mm}$-diameter Petri dishes, each containing $25 \mathrm{~mL}$ of culture medium. The number of anthers per petridish was 50 . The dishes were sealed with Parafilm and incubated in the dark at $25 \pm 2^{\circ} \mathrm{C}$. Three replicated plates were used per treatment for each experiment.

To hasten the growth of shoots derived from embryos were transferred into the culture tubes $(25 \times 150 \mathrm{~mm}$; Borosil, India) containing $10 \mathrm{ml}$ of liquid MS medium supplemented with $0.5 \mathrm{mg} / \mathrm{L} \mathrm{BA}, 0.1 \mathrm{mg} / \mathrm{L} \mathrm{NAA}$ and
$3.0 \%$ sucrose and then sequentially sub-cultured on the same media at fifteen days intervals up to forty five days. The developed shoots were treated with different concentrations $(0.5-4.0 \mathrm{mg} / \mathrm{L})$ of indole-3-butyric acid (IBA) to promote rooting. All plantlets were maintained for ten to twelve weeks at $25 \pm 2^{\circ} \mathrm{C}$ and $60-65 \%$ relative humidity under a 16/8 h (light/dark) photoperiod with light supplied by cool-white fluorescent tubes (Philips, India) at an intensity of $48 \mu \mathrm{mol} / \mathrm{m}^{2} \mathrm{~s}^{2}$. In the present investigation, the effects of high temperature, starvation and physical state of media on embryo induction were observed.

Hardening and acclimatization of plantlets: The well rooted tissue cultured plantlets were carefully transferred to the vermiculite pots supplemented with full strength Hyponex solution (N:7, P:6, K:19). These were hardened in a hardening chamber with gradually controlling temperature, humidity and light as the ambient conditions. The established plantlets after acclimatization were transferred in polythene bags under ambient conditions. After one month of acclimatization, the anther cultured plantlets were ready to transplant into the field.

Statistical analysis: Data on embryo induction and in vitro rooting were recorded at regular time intervals for all treatments. All the experiments were carried out in a complete randomized design maintained with three replicates and each experiment was repeated thrice. The effect of different treatments on in vitro androgenesis in papaya was quantified and the data was statistically analyzed by using software OPSTAT 1.0.

\section{RESULTS}

In the present investigation, the experiments were conducted to investigate the effects of high temperature, starvation and physical state of media along with exogenous hormones on in-vitro androgenesis in papaya $c v$. Pusa Nanha. In the present investigation, following results were observed. Effects of temperature, starvation and physical state of media on embryo induction: In the present investigation, fifty anthers of papaya $c v$. Pusa Nanha were used for each treatment. No embryo formation was observed from anthers pre-treated in water and of MS nutrients medium with or without sucrose at $20^{\circ} \mathrm{C}$. On the other hand, embryos were induced on anthers pre-treated in liquid medium at both $25^{\circ} \mathrm{C}$ and $35^{\circ} \mathrm{C}$ as shown in table 1 . At $25^{\circ} \mathrm{C}$, embryos were formed at a rate of 2.0-4.0\% when anthers were pre-treated in MS liquid + sucrose medium for four and seven days. At $25^{\circ} \mathrm{C}$ embryo induction was also observed at a rate of $4.0 \%$ when anthers were incubated in water for one day. At $35^{\circ} \mathrm{C}$, embryos were induced at the rate of 6.0 $\%$ upon incubation of anthers in water for one day and at the rate of $4.0 \%$ in MS liquid medium for four days and at the rate of $8.0 \%$ in MS liquid medium with $2.0 \%$ sucrose for seven days. Starvation effects were clearly indicated that the presence of sucrose in the media was essential for optimum embryo induction from anthers (Table 1). 
Table 1. Embryo induction on anthers at agar medium with $0.1 \mathrm{mg} / \mathrm{L} \mathrm{BA}$ and $0.1 \mathrm{mg} / \mathrm{L}$ NAA after pre-treated in water and MS liquid medium with or without sucrose at $20^{\circ} \mathrm{C}, 25^{\circ} \mathrm{C}$ and $35^{\circ} \mathrm{C}$.

\begin{tabular}{|c|c|c|c|c|}
\hline $\begin{array}{c}\text { Temperature } \\
\left({ }^{\circ} \mathrm{C}\right)\end{array}$ & Medium & Duration (Days) & No. of anthers used & $\begin{array}{l}\text { No. of anthers formed } \\
\text { embryos }(\%)\end{array}$ \\
\hline \multirow{10}{*}{20} & \multirow{3}{*}{ Water } & 1 & 50 & 0 \\
\hline & & 4 & 50 & 0 \\
\hline & & 7 & 50 & 0 \\
\hline & \multirow{4}{*}{ MS } & 1 & 50 & 0 \\
\hline & & 4 & 50 & 0 \\
\hline & & 7 & 50 & 0 \\
\hline & & 1 & 50 & 0 \\
\hline & \multirow[t]{3}{*}{ MS $+2.0 \%$ Sucrose } & 4 & 50 & 0 \\
\hline & & 7 & 50 & 0 \\
\hline & & 1 & 50 & $2(4.0)$ \\
\hline \multirow{8}{*}{25} & \multirow[t]{3}{*}{ Water } & 4 & 50 & $1(2.0)$ \\
\hline & & 7 & 50 & 0 \\
\hline & & 1 & 50 & 0 \\
\hline & \multirow[t]{3}{*}{ MS } & 4 & 50 & $1(2.0)$ \\
\hline & & 7 & 50 & $2(4.0)$ \\
\hline & & 1 & 50 & 0 \\
\hline & \multirow[t]{3}{*}{ MS $+2.0 \%$ Sucrose } & 4 & 50 & $2(4.0)$ \\
\hline & & 7 & 50 & $3(6.0)$ \\
\hline \multirow{9}{*}{35} & & 1 & 50 & $3(6.0)$ \\
\hline & \multirow[t]{2}{*}{ Water } & 4 & 50 & $2(4.0)$ \\
\hline & & 7 & 50 & $1(2.0)$ \\
\hline & \multirow{4}{*}{ MS } & 1 & 50 & $1(2.0)$ \\
\hline & & 4 & 50 & $2(4.0)$ \\
\hline & & 7 & 50 & $1(2.0)$ \\
\hline & & 1 & 50 & $1(2.0)$ \\
\hline & \multirow[t]{2}{*}{ MS $+2.0 \%$ Sucrose } & 4 & 50 & $3(6.0)$ \\
\hline & & 7 & 50 & $4(8.0)$ \\
\hline
\end{tabular}

The highest embryo induction rate $(8.0 \%)$ was observed when anthers were cultured on agar medium supplemented with $0.1 \mathrm{mg} / \mathrm{L} \mathrm{BA}$ and $0.1 \mathrm{mg} / \mathrm{L}$ NAA after incubation in liquid MS medium supplemented with $2.0 \%$ sucrose for seven days at $35^{\circ} \mathrm{C}$. These results indicated that the pre-treatment of anthers in liquid MS medium are effective for embryo induction at $35^{\circ} \mathrm{C}$ than at $25^{\circ} \mathrm{C}$. The present investigation suggested that high temperature $\left(35^{\circ} \mathrm{C}\right)$ was more suitable for embryo induction in papaya than slightly low temperature $\left(25^{\circ} \mathrm{C}\right)$ as shown in table 1 . At both temperatures $\left(25^{\circ} \mathrm{C}\right.$ and $\left.35^{\circ} \mathrm{C}\right)$ longer incubation of anthers in water reduced embryo induction rate (Table 1). The effect of sugar starvation treatment on embryo induction was ambiguous.

Effects of different concentrations of IBA on rooting: In the present study, well developed shoots on liquid MS medium supplemented with $0.5 \mathrm{mg} / \mathrm{L} \mathrm{BA}, 0.1 \mathrm{mg} /$ L NAA and 3.0\% sucrose were used for in vitro rooting experiments. Twenty shoots were used for in vitro rooting in each treatment. An auxin-IBA (0.0-4.0 mg/ L) was used for rooting of in-vitro developed shoots (Table 2). The results indicated that $1 / 2 \mathrm{MS}$ supplemented with $2.0 \mathrm{mg} / \mathrm{L}$ IBA produced highest rooting (75.0\%). Increasing IBA concentrations reduced rooting percentage. Rooting (15.0\%) was also obtained on $1 / 2$ MS media without IBA. In the present study, no callus formation was observed during the rooting of shoots.

Hardening and field acclimatization of plantlets: Out of 140 plantlets used for rooting only 44 plantlets showed vigorous rooting while 10 plantlets showed weak rooting. These well rooted plantlets were transferred to hardening chamber for hardening. After hardening, only 30 plants survived. These plants were carefully transplanted to field for further investigation.

\section{DISCUSSION}

Successful in-vitro androgenesis depends on various factors, e.g., genotype and physiological state of the donor plant, microspore developmental stages, culture medium, and pre-culture treatments (Palmer and Keller, 1997; Rimberia et al., 2005 and 2006; Azad et al., 2013). Growth regulators in culture media are one of the most important components for pollen embryogenesis via anther culture (Zhang and Lespinasse, 1992; Sopory and Munshi, 1996; Rimberia et al., 2005 \& 2006; Azad et al., 2013). In some plant species, an auxin or a cytokinin alone is required for inducing pollen embryogenesis (Sopory and Munshi, 1996), while in others, such as cereals and fruit crops, a combination of both auxins and cytokinins are necessary (Bajaj, 1990; Zhang and Lespinasse, 1992; Ochatt and Zhang, 1996; Rimberia et al., 2005 and 2006; Azad et al., 
Table 2. Effects of different IBA concentrations on in vitro rooting of papaya shoots (Mean $\pm \mathrm{SD}$ of three replicates).

\begin{tabular}{|c|c|c|c|c|c|}
\hline $\begin{array}{c}\text { IBA } \\
\text { Concentration } \\
(\mathrm{mg} / \mathrm{L})\end{array}$ & $\begin{array}{l}\text { Number of } \\
\text { shoots used for } \\
\text { root induction }\end{array}$ & $\begin{array}{l}\text { Number and \% } \\
\text { of shoots showing } \\
\text { root induction }\end{array}$ & $\begin{array}{l}\text { Number of } \\
\text { roots/shoot } \\
(\text { Mean } \pm \text { SD) }\end{array}$ & $\begin{array}{l}\text { Root length } \\
\quad(\mathrm{cm}) \\
(\text { Mean } \pm \text { SD })\end{array}$ & $\begin{array}{c}\text { Callus } \\
\text { induction }\end{array}$ \\
\hline $1 / 2 \mathrm{MS}+0.00$ & 20 & $3(15.0)$ & $1.20 \pm 0.15$ & $0.75 \pm 0.20$ & ++ \\
\hline $1 / 2-M S+0.25$ & 20 & $5(25.0)$ & $1.65 \pm 0.32$ & $1.35 \pm 0.26$ & + \\
\hline $1 / 2-\mathrm{MS}+0.50$ & 20 & $7(35.0)$ & $1.90 \pm 0.55$ & $1.58 \pm 0.37$ & + \\
\hline $1 / 2-\mathrm{MS}+1.00$ & 20 & $10(50.0)$ & $2.35 \pm 0.48$ & $2.05 \pm 0.47$ & --- \\
\hline $1 / 2-\mathrm{MS}+2.00$ & 20 & $15(75.0)$ & $3.70 \pm 0.75$ & $3.40 \pm 0.76$ & --- \\
\hline $1 / 2-\mathrm{MS}+3.00$ & 20 & $8(40.0)$ & $3.20 \pm 0.84$ & $2.80 \pm 0.45$ & +++ \\
\hline $1 / 2-\mathrm{MS}+4.00$ & 20 & $6(30.0)$ & $1.86 \pm 0.62$ & $1.28 \pm 0.34$ & +++ \\
\hline
\end{tabular}

Here, +++ High, ++ Medium, + Low, --- None

2013).

In the present study, the effects of different temperatures, starvation and physical state of media on embryo induction were analyzed. Highest embryo induction rate $(8.0 \%)$ was observed when anthers were cultured on agar medium with $0.1 \mathrm{mg} / \mathrm{L} \mathrm{BA}$ and $0.1 \mathrm{mg} / \mathrm{L}$ NAA after incubation in liquid MS medium with $2.0 \%$ sucrose for 7 days at $35^{\circ} \mathrm{C}$. These results are supported from the results of Rimberia et al. (2005). In their experiments, highest embryo induction rate (rate of anthers forming embryos) was $4.2 \%$ on agar medium with $0.1 \mathrm{mg} / \mathrm{L} \mathrm{BA}$ and 0.1 $\mathrm{mg} / \mathrm{L}$ NAA after pre-treating anthers in water for 1 day at $35^{\circ} \mathrm{C}$. The results of the present study indicated that the pre-treatment of anthers in liquid medium 1-7 days was effective for embryo induction, and that the pre-treatment at $35^{\circ} \mathrm{C}$ tends to be more efficient for embryo induction than that at $25^{\circ} \mathrm{C}$. Therefore, it seems that liquid medium and high temperature are important for inducing embryos from anthers. At these both temperatures longer incubation of anthers in water reduced embryo induction rate. The pre-treatment of anthers at low and high temperatures is also effective for embryo induction in anther culture of many plant species including cereals e.g. rice (Ying, 1986; Sopory and Munshi, 1996).

The effect of nutrients and sugar starvation on embryo induction during pre-treatment was ambiguous. Moreover, the starvation treatments are known to be efficient for embryo induction (Sangwan and Sangwan-Norreel, 1996; Rimberia et al., 2005). In the present study, the
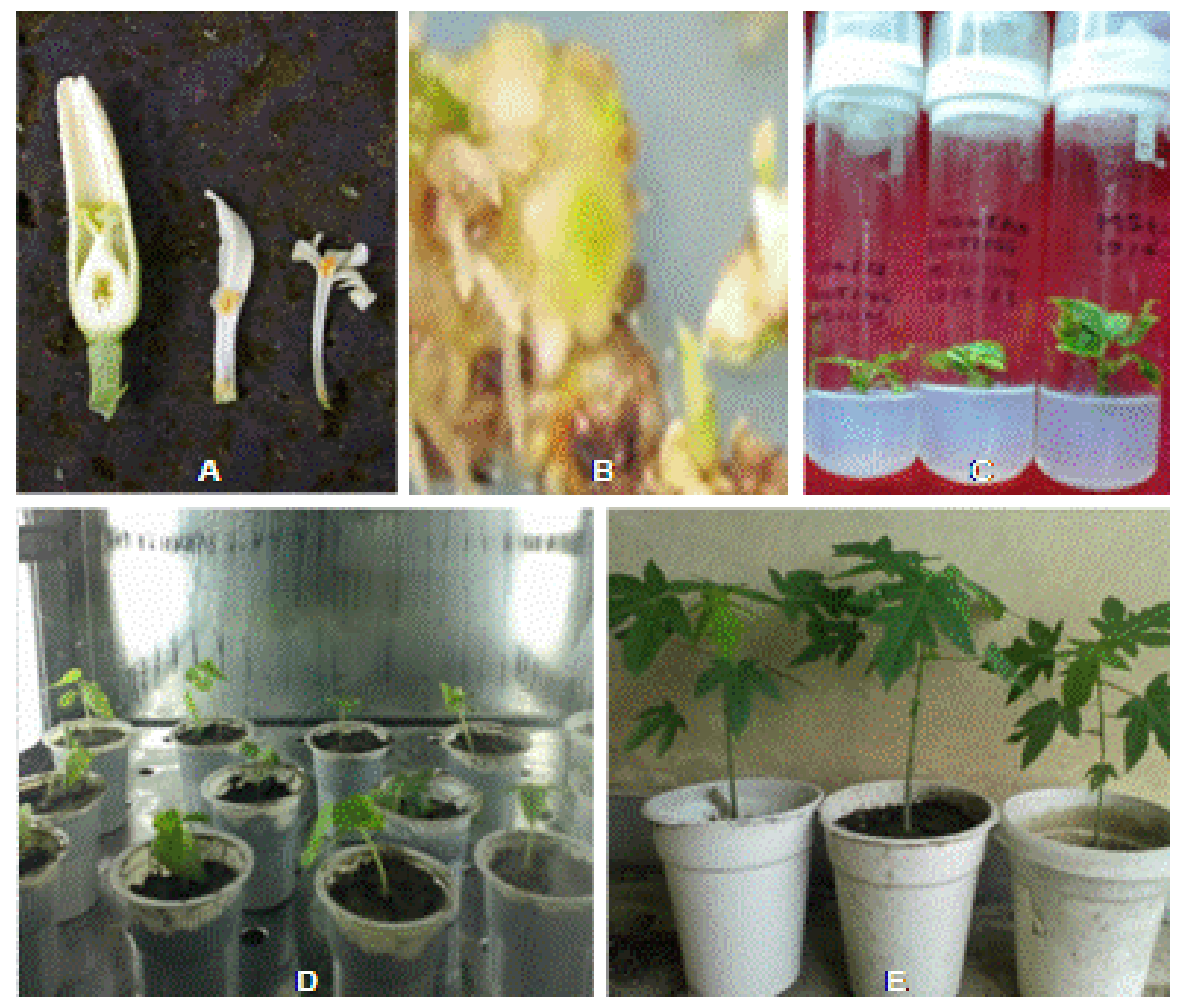

Fig. 1. In vitro androgenesis in papaya (A) Papaya flower buds showing anthers (B) Embryogenic callus induction and shoot regeneration $(C)$ Shoots ready for rooting $(D)$ Hardening of rooted plants in hardening chamber $(F)$ Acclimatized plants transferred to vermiculate pots. 
effects of IBA on rooting were also observed. The results showed that $2.0 \mathrm{mg} / \mathrm{L}$ IBA gave highest rooting (75.0\%). Increasing in IBA concentration reduced rooting percentage. Callus formation was also observed through the basal ends of plantlets on basal $1 / 2$-MS media and with slightly lower as well as higher IBA concentrations. The rooting results were closer to those of reported by earlier workers in papaya (Rajeevan and Pandey, 1983 and 1986; Drew, 1988; Mondal et al., 1990; Kataoka and Inoue, 1991; Rimberia et al., 2005). However, Wilna (1988) reported that, $4.0 \mathrm{mg} / \mathrm{L}$ of IBA was more effective on in vitro rooting of papaya. On the other hand, Litz and Conover (1978) found that NAA at 1.0 $\mathrm{mg} / \mathrm{L}$ concentration was best for papaya in vitro rooting. In this study, after hardening 30 plants were successfully transplanted to the field.

\section{Conclusion}

In the present study, it was concluded that higher temperature was more suitable for embryo induction in papaya than low temperature. At these temperatures longer incubation of anthers in water reduced embryo induction rate in anthers. Sugar starvation results were ambiguous. Shoots were also developed on the above media while used in liquid form. Best rooting $(75.0 \%)$ was observed at $2.0 \mathrm{mg} / \mathrm{L}$ IBA. Increasing in IBA concentration adversely affected rooting in shoots. All well rooted plants were hardened and successfully transferred to field. In this study, the embryo induction rate was generally low, and a few embryos developed directly into plantlets but most of them produced multiple embryos or calli. To overcome these problems, there is need to established optimal cultural conditions for normal development and acclimatization of plantlets, i.e. many plantlets were also died during these processes. For the development of an efficient haploid production system in papaya, the standardization of in vitro cultural conditions and their effects on normal embryo induction is an essential but critical step. Therefore, the present study would be helpful to the researchers to develop more efficient anther culture protocols for further improvement of papaya through in vitro androgenesis.

\section{REFERENCES}

Azad, M.A.K., Rabbani, M.G. and Amin, L. (2013). Effects of different culture media and flower bud size on haploid plant production through anther culture of three Carica species. Journal of Food, Agriculture \& Environment, 11 (2):296-300.

Badillo, V.M. (1971). Monografia de la Familia Caricaceae. Maracay, Venezuela. p. 222.

Bajaj, Y.P.S. (1990). In vitro production of haploids and their use in cell genetics and plant breeding. Springer Verlag, Berlin Heidelberg.

Bajaj, Y.P.S. (1983). In vitro production of haploids. In: Handbook of Plant Cell Culture, Vol. 1: Techniques for Propagation and Breeding. Ed. D.A. Evans et al. Macmillan, New York. pp. 228-287.

Dallwitz, M.J. (1980). A general system for coding taxonomic descriptions. Taxon, 29:41-46.

Drew, R.A. (1988). Rapid clonal propagation of papaya in vitro from mature field grown trees. Hort. Sci., 23:609-611.

Drew, R.A. (2003). Micropropagation of Carica papaya and related species. In: Jain SM, Ishii K (Eds.). Micropropagation of woody trees and fruits. Kluwer Academic Publishers, Netherlands. pp. 543-564.

Dunwell, J.M. (1996). Microspore culture. In: In Vitro Haploid Production in Higher Plants, Vol. 1: Fundamental Aspects and Methods. Eds. SM Jain, SK Sopory and RE Veilleux. Kluwer Academic Publishers, Dordrecht, the Netherlands. pp. 205-216.

Guha, S. and Maheshwari, S.C. (1964). In vitro production of embryos from anthers of Datura. Nature, 204:496.

Heberle-Bors, E. (1985). In vitro haploid formation from pollen: a critical review. Theor. Appl. Genet., 71:361-374.

Indian Horticulture database (2011). Source: www.nhb.gov.in. Kataoka, I. and Inoue, H. (1991). Rooting of tissue cultured papaya shoots under ex vitro conditions. Japan J. Trop. Agr., 35(2):127-129.

Litz, R.E. and Conover, R.A. (1978). In vitro propagation of papaya. Hort. Sci., 13:241- 242.

Litz, R.E. and Conover, R.A. (1979). In Vitro improvement of Carica papaya L. Amer. Soc. Hortic. Sci., 23:157-159.

Maheshwari, S.C., Rashid, A. and Tyagi, A.K. (1982). Haploids from pollen grains- retrospect and prospect. Amer. $J$. Bot., 69:865-879.

Mondal, M., Gupta, S. and Mukherjee, B.B. (1990). In vitro propagation of shoot buds of Carica papaya L. (Caricaceae) var. Honey Dew. Plant Cell Rep., 8:609-612.

Murashige, T. and Skoog, F. (1962). A revised medium for rapid growth and bioassays with tobacco tissue cultures. Physiol. Plant., 15:473-479.

Ochatt, S.J. and Zhang, Y.X. (1996). In vitro haploidization of fruit trees. In: S.M. Jain, S.K. Sopory and R.E. Veilleux $(E d s)$. In vitro Haploid Production in Higher Plants. vol. 2, Kluwer Academic Publishers, Dordrecht. pp. 193-210.

Palmer, C.E. and Keller, W.A. (1997). Pollen embryos. In: K.R. Shivanna and V.K. Sawhney $(E d s)$, Pollen biotechnology for crop production and improvement, Cambridge University Press, New York. pp. 392-422.

Rajeevan, M.S. and Pandey, R.M. (1983). Propagation of papaya through tissue culture. Acta Hortic., 131:131-139.

Rajeevan, M.S. and Pandey, R.M. (1986). Lateral bud culture of papaya (Carica papaya L.) for clonal propagation. Plant Cell Tiss. Org. Cult., 6:181-188.

Ray, P.K. (2002). Breeding Tropical and Subtropical Fruits. Narosa Publishing House, New Delhi, pp. 106-128.

Rimberia, F.K., Sunagawa, H., Urasaki, N., Ishimine, Y. and Adaniya, S. (2005). Embryo induction via anther culture in papaya and sex analysis of the derived plantlets. Sci. Hortic., 103:199-208.

Rimberia, F.K., Adaniya, S., Etoh, T. and Ishimine, Y. (2006). Sex and ploidy of anther culture derived papaya (Carica papaya L.). Euphytica, 149:53-59.

Sangwan, R.S. and Sangwan-Norreel, B.S. (1996). Cytological and biochemical aspects of in vitro androgenesis in higher plants. In: SM Jain, SK Sopory, RE Veilleux (Eds.), In vitro Haploid Production in Higher Plants, vol. 1. Kluwer Academic Publishers, Dordrecht, pp. 95-109.

Silva, J.A.T., Rashid, Z., Nhut, D.T., Sivakumar, D., Gera, A., Souza, J.M.T. and Tennant, P.F. (2007). Papaya (Carica papaya L.) biology and biotechnology. Tree for. Sci. Biotech., 1:47-73.

Sopory, S. and Munshi, M. (1996). Anther culture. In: S M 
Jain, S K Sopory, Veilleux R E(Eds.), In vitro Haploid Production in Higher Plants, vol. 1. Kluwer Academic Publishers, Dordrecht, $p p$. 145-176.

Tsay, H.S. and Su, C.Y. (1985). Anther culture of papaya (Carica papaya L.). Plant Cell Rep., 4:28-30.

Wilna, D.W. (1988). Clonal propagation of papaya in vitro. Plant Cell Tiss. Org. Cult., 12:205-210.

Ying, C. (1986). Anther and pollen culture of rice. In: H.
Han and Y. Hongyuan (Eds.), Haploids of Higher Plants In Vitro. Springer-Verlag, Berlin, pp. 3-25.

Zhang, Y.X. and Lespinasse, Y. (1992). Haploidy. In: F.A. Hammerschlag and R.E. Litz (Eds.), Biotechnology of perennial fruit crops, CAB International, Oxon. pp. 57-75

Zhang, J., Shen, W., Yan, P., Li, X. and Zhou, P. (2011). Factors that influence the yield and viability of protoplasts from Carica papaya L. Afr. J. Biotech., 10:5137-5142. 